\title{
REFLEKSIVNO OBRAZOVANJE ZA INKLUZIVNU NASTAVU - STANJE I PERSPEKTIVE
}

\author{
Jelena Maksimović ${ }^{1}$, Jelena Osmanović \\ Univerzitet u Nišu, Filozofski fakultet u Nišu, Departman za pedagogiju
}

\begin{abstract}
Apstrakt: Izazovi sa kojima se nastavnici susreću razlikuju se u odnosu na to da li nastavnik radi sa učenicima osnovnoškolskog ili srednjoškolskog uzrasta. S obzirom na to da ovim istraživanjem želimo da otkrijemo i ukažemo na najvažnije izazove sa kojima se nastavnici susreću, posebnu pažnju ćemo posvetiti analiziranju uloge nastavnika refleksivnog praktičara u procesu inkluzivne nastave, kao jednom od potencijalnih izazova sa kojima se susreće na putu profesionalnog razvoja, čime ćemo makar jednim delom doprineti olakšavanju njihovog daljeg rada i učiniti ga efikasnijim. Rezultati istraživanja su pokazali da nastavnici bez obzira na to da li rade u osnovnim ili srednjim školama jesu prijemčivi prema promenama koje se dešavaju. Ako jesu otvoreni, postavlja se pitanje zašto su pokazali negodovanje i rezervisanost prema sprovođenju inkluzivne nastave? U istraživanju je učestvovalo 209 nastavnika na teritoriji grada Niša. Podaci su prikazani deskriptivnom analizom i tabelarnim putem.
\end{abstract}

Ključne reči: refleksivno obrazovanje, refleksivna praksa, refleksivni praktičar, inovacije u obrazovanju, inkluzivno obrazovanje.

\section{Profesionalno i stručno usavršavanje nastavnika refleksivnog praktičara u društvu obrazovnih inovacija}

Profesionalno i stručno usavršavanje nastavnika refleksivnog prakričara zahteva fleksibilnost i eksperimentisanje u nastavi, kao i razvijajnje kritičkog stava prema brojnim inovacijama i predlozima (Maksimović i Banđur, 2013). Aktivno eksperimentisanje u refleksivnoj nastavi može dovesti do kreativnih promena i napredovanja nastavnika refleksivnog praktičara. Džinović (2010) ove promene označava kao izuzetno značajne, pri čemu ukazuje na neke od njihovih preduslova i karakteristika: profesionalna promena je proces koji je neophodno sagledavati u razvojnoj i vremenskoj perspektivi; postoje značajne individualne razlike u procesu profesionalne promene i razvoja; svaka razvojna profesionalna promena se ne dešava lako, niti brzo i uvek predstavlja potencijal za napredak, ali i rizik da će njen neuspeh ugroziti

\footnotetext{
${ }_{1}^{1}$ jelena.maksimovic@filozofski.rs
} 
izglede za budući profesionalni razvoj. Značaj ovih promena usmeren je u inoviranju i unapređivanju nastavnog procesa. Skupovi međusobno povezanih obeležja i pretpostavki, kako navode Stanković i Pavlović (2010), nazivaju se modelima profesionalnog razvoja, stavljajući akcenat na to da je termin pristup prikladniji od termina model. Međutim, većina autora odlučuje se za drugi termin, model profesionalnog razvoja, da bi se izbegao terminološki nesporazum.

Modeli profesionalnog razvoja mogu se razvrstati u dve osnovne grupe, a to su modeli deficita i modeli razvoja (Huberman, 1995). Između ova dva modela javlja se tenzija kao izvor različitosti, jer prvi model insistira na ideji da nastavnici poseduju nedostatke, kao i to da su neophodne korekcije i dopune u procesu profesionalnog usavršavanja nastavnika. Drugi model predstavlja usavršavanje nastavnika kao kontinuirano traganje u ličnoj praksi. U prvom modelu nastavnici su u pasivnoj ulozi, koja im uskraćuje mogućnost kreativnosti i pokušaja izmene sopstvenog rada i napredovanja, a u drugom modelu nastavnicima je pruženo obilje informacija preko različitih oblika rada, koji ih podstiču na promenu.

Sve veći broj teorijskih i empirijskih istraživanja na našim prostorima kada je reč o modelima profesionalnog razvoja govore o nastavniku istraživaču, refleksivnom praktičaru, istraživaču sopstvene refleksivne prakse u kojoj ispitivanjem ličnih kapaciteta, nalazi najbolji put profesionalnog napredovanja i razvoja.

Vlahović i Vujisić-Živković (2005) ukazuju da znanja koja budući nastavnici releksivni praktičari stiču kroz inicijalno obrazovanje nemaju veliku upotrebnu vrednost, nisu usko konkretizovana i svrsishodna praktičnim potrebama u radu. Najčešće ne omogućavaju reorganizaciju situacije, te ovi autori ukazuju na postojanje četiri tradicije u profesionalnom obrazovanju nastavnika: 1. Obrazovanje za veštine, u kome se profesija definiše preko stepena praktičnih kompetencija. Veštine uključuju manifestno ponašanje u učionici i identifikuju se sa poučavanjem; 2. Obrazovanje za implementaciju teorije opštih principa nastave, gde se profesionalna delatnost definiše kao prevođenje pedagoške teorije u nastavnu praksu; 3. Obrazovanje za promišljeno delovanje koje u osnovi ima Šinovo učenje o refleksivnom praktičaru, gde je suština profesije u sposobnosti rešavanja problema i donošenju odluka; 4 . Obrazovanje za kritičku analizu i refleksiju.

Ako nastavnik primenjuje isključivo opšte principe koje su osmislili obrazovni stručnjaci, onda je cilj profesionalnog obrazovanja ovladavanje pedagoškom teorijom, zbog čega se gubi veza sa refleksivnom praksom. Novi koncept kao cilj postavlja obrazovanje nastavnika sposobnog za interpretaciju, razumevanje i istraživanje obrazovanja. Vlahović i Vujisić-Živković (2005) takođe ukazuju na poseban problem našeg prostora, to je selekcija kandidata za učiteljske fakultete, okarakterisana kao negativna, dok se nastavnička profesija nalazi u grupi ne tako popularnih zanimanja, jer se za ovu profesiju najčešće opredeljuju kandidati sa skromnijim rezultatima, ali i oni koji nisu imali uspeha u željenim zanimanjima, pa iz tog razloga nastavnički i učiteljski fakulteti predstavljaju kompenzacijsku mogućnost. Posebno ukazujući na značaj inicijalnog obrazovanja, ovi autori akcenat stavljaju na neusaglašenost ciljeva savremenog obrazovanja nastavnika i metoda rada koje se izuzetno sporo menjaju. 
Tradicionalna nastava ne može proizvesti nastavnika sa modernom vizijom nastave i metodama rada. Kod nastavnika je veoma učestala identifikacija sa već viđenim procesom nastave, što ujedno predstavlja i najjednostavniji način za realizaciju nastavnih sadržaja. Zato se danas impliciraju brojne inovacije u obrazovnom sistemu kako bi se ti nastavni sadržaji realizovali na mnogo zanimljiviji, bolji i uspešniji način, prvenstveno za aktere vaspitno-obrazovnog procesa - učenike.

Nastavnička profesija izuzetno je kompleksna i kao takva zahteva dosta zalaganja, odricanja i posvećenosti vaspitno-obrazovnom radu (Bjekić, 1999). Sa razvojem nauke i tehnologije, sa uvođenjem brojnih promena u obrazovno-vaspitni sistem, nastavnici su se našli pred brojnim izazovima od koji ne smeju bežati, već sa kojima se moraju suočiti i uskladiti ih sa svojim sistemom vrednosti, stilom rada i ličnošću, ukoliko žele biti uspešni u svom poslu.

Interakcija i podučavanje učenika, kao i saradnja sa drugim članovima obrazovnog procesa, prepuni su stresnih situacija koje su u uskoj vezi sa elementima svakog obrazovnog sistema. Povećana odgovornost za učenike i njihov uspeh, učeničko nasilje, preveliki broj učenika u odeljenju, nedostatak prostora za održavanje nastave, slaba opremljenost škole savremenim nastavnim sredstvima, niska novčana nadoknada, visoki zahtevi profesije, uvođenje novih metoda rada, pritisci sa svih strana, samo su neki od razloga zbog kojih se nastavnik može osećati ogorčenim i nezadovoljnim (Grujić, 2011). Brojne teškoće i izazovi sa kojima se nastavnici u svom radu susreću imaju kao rezultat negativne posledice koje se odražavaju ne samo na njih same, već i na učenike i njihovo postignuće u školi (Ibid.). U takvim okolnostima nastavnici su manje kreativni, pozitivni i optimistični.

Izazovi sa kojima se nastavnici susreću se donekle razlikuju u odnosu na to da li nastavnik radi sa učenicima osnovnoškolskog ili srednjoškolskog uzrasta. S obzirom na to da ovim radom želimo da otkrijemo i ukažemo na najvažnije izazove sa kojima se nastavnici susreću, posebnu pažnju ćemo posvetiti analiziranju uloge nastavnika refleksivnog pratičara u procesu inkluzivne nastave, kao jednim od potencijalnih izazova sa kojima se susreće na putu ka realizaciji svoje profesionalne uloge, čime ćemo makar jednim delom doprineti olakšanju njihovog daljeg rada $\mathrm{i}$ učiniti ga efikasnijim.

\section{Inkluzivna nastava izazov za refleksivne praktičare}

Da bi uopšte bilo moguće govoriti o inkluziji u školi potrebno je pre svega izvršiti promene kako u samoj organizaciji školskog sistema, tako i u svim ostalim njegovim segmentima. Savremena škola podrazumeva promene u okviru kojih će učenici zauzimati centralnu ulogu i gde će imati mogućnost za slobodan intelektualni, emocionalni i socijalni razvoj (Hozić, 2009). Izuzev ovoga, savremena škola podrazumeva i integraciju dece sa smetnjama u razvoju.

Pre nego što uopšte pređemo na analizu nastavnikovog ponašanja i realizacije njegove uloge $u$ inkluzivnom obrazovanju, važno je objasniti šta se pod pojmom 
inkluzivna nastava i obrazovanje podrazumeva. Naime, inkluzija je proces koji podrazumeva razvijenu svest društva o jednakim pravima svih pojedinaca, pa shodno tome i uključivanje dece sa posebnim potrebama u redovna školska odeljenja, gde im se pruža mogućnost da učestvuju u svim vrstama aktivnosti koje čine savremenu školu i savremeno društvo (Dedaj, 2011; Dimitrijević, 2010; Grandić i Stipić, 2011; Hozić, 2009; Petković, 2009). Dakle, inkluzivno obrazovanje je jednom rečju obrazovanje dostupno svima, bez izuzetka.

Inkluzivni razvoj škole zahteva jedan sasvim nov način razmišljanja i svest ljudi. To takođe sa sobom povlači i potrebu da se redukuje uloga nastavnika, naročito njegova uloga refleksivnog praktičara koja podrazumeva sledeće (Golubović i Maksimović, 2008): potrebno je da nastavnik dobro poznaje domen rada sa decom ometenom u razvoju i da ima volju za rad sa njima; potrebno je da istovremeno uviđa, uvažava i poštuje individualne razlike koje među decom postoje i ceni njihove sposobnosti; potrebno je da nastavnik raspolaže stručnim znanjima, da je osposobljen za timski rad i da je spreman da se permanentno obrazuje i usavršava; potrebna je i osposobljenost nastavnika za izradu individualnog plana i programa rada.

Važno je da nastavnik refleksivni praktičar u inkluzivnoj nastavi ima i ulogu savetnika i pomoćnika u učenju učenicima, bez autoritarnosti. Nastavnik refleksivni praktičar prema učenicima mora pokazati razumevanje i podsticati ih na aktivnost. Nastavnik refleksivni praktičar u procesu inkluzivne nastave mora da teži tome da prilagođava svoj stil zahtevima refleksivne nastave, da se suočava sa problemima i otvara nove perspektive u svom radu.

\section{Metodološki deo}

Kako se razmatranje uloge nastavnika ne bi svelo samo na teoriju, već da bi se nešto učinilo po pitanju modela profesionalnog usavršavanja, važno je upoznati se sa svim novitetima koje je donelo moderno doba i osavremenjivanje obrazovanja, kao i svim izazovima u radu nastavnika. Na osnovu toga postavljen je problem ovog istraživanja: Koji su potencijalni izazovi sa kojima se susreću nastavnici refleksivni praktičari u vaspitno-obrazovnoj praksi?

Predmet ovog istraživanja jesu stavovi nastavnika refleksivnih praktičara o izazovima sa kojima se susré́u u nastavnom procesu i radu sa učenicima.

Opšti cilj ovog istraživanja jeste istražiti, analizirati i utvrditi sa kojim izazovima se susreću nastavnici refleksivni praktičari u obrazovno-vaspitnom procesu. Posebni ciljevi ovog istraživanja usmereni su na ispitivanje stavova nastavnika refleksivnih praktičara o profesionalizaciji i demokratizaciji njihovog poziva, da li prihvataju inovacije u svom radu, kao i šta predstavlja najveći izazov od onih sa kojima se susreću.

Nezavisne varijable se odnose na osnovne karakteristike populacije koje su bile obuhvaćene istraživanjem, a to su: dužina radnog staža ispitanika (0-10 godina, 11-20 godina i preko 20 godina), kao i tip obrazovne ustanove u kojoj su ispitanici 
zaposleni (osnovna škola i srednja škola). Istraživanje je vršeno na namernom uzorku koji je činilo 209 nastavnika na teritoriji grada Niša. U skladu sa napred navedenim, u istraživanju je korišćena deskriptivna metoda, kao i metoda teorijske analize, kako bi se istraživanje potkrepilo teorijskom osnovom, zatim servay istraživački metod koji je korišćen prilikom kvantitativne obrade podataka.

U odnosu na problem koji je postavljen u ovom radu korišćena je tehnika skaliranja, instrument skale procene Likertovog tipa (SLT1) koji je sačinjen od 35 ajtema.

Metrijske karakteristike instrumenta ispitali smo pomoću Cronbah alfa testa, kako bismo utvrdili da li instrument, konstruisan za potrebe ovog istraživanja zadovoljava kriterijum pouzdanosti.

\begin{tabular}{cc} 
Tabela 1. Pouzdanost konstruisanog instrumenta \\
\hline Cronbach's Alpha & N of Items \\
\hline 0.82 & 35 \\
\hline
\end{tabular}

$\mathrm{Na}$ osnovu podataka dobijenih u tabeli možemo videti da Cronbach Alpha iznosi 0,82 i utvrdili smo da on zadovoljava kriterijum pouzdanosti konstruisanog instrumenta. Cronbah alfa koeficijent pokazuje da svi ajtemi (35) mere istu pojavu, tj. da su konzistentni. Postupkom faktorske analize zadržali smo dva konzistentna faktora, prvi koji se odnosi na inovacije u nastavi, drugi faktor odnosi se na inkluzivno obrazovanje, kao glavna izvora izazova sa kojima se susreću nastavnici.

\section{Analiza i interpretacija rezultata istraživanja}

Školski sistem sa kojim se danas susrećemo odlikuju mnogobrojne promene i inovacije sa kojima se nastavnici nužno suočavaju. S obzirom na to da veliki broj nastavnika izražava nepoverenje prema bilo kojoj novini i drži se već proverenog i ustaljenog načina rada dugi niz godina, želeli smo da ovim istraživanjem ispitamo da li se situacija donekle promenila ili su inovacije još uvek veliki izazov nastavnicima. Dobijene podatke možemo videte u Tabeli 2.

Tabela 2. Stavovi ispitanika o promenama i novim oblicima rada s obzirom na tip škole

\begin{tabular}{|c|c|c|c|c|c|c|}
\hline Tvrdnje & $\begin{array}{l}\text { Tip obrazovne } \\
\text { ustanove }\end{array}$ & M & SD & t-test & $\mathbf{p}$ & df \\
\hline \multirow{2}{*}{$\begin{array}{l}\text { Materijalno-tehnička opremljenost } \\
\text { škole pruža mogućnost za } \\
\text { realizaciju mojih zamisli i ideja. }\end{array}$} & osnovna škola & 3.16 & 1.18 & & & \multirow{2}{*}{98} \\
\hline & srednja škola & 3.24 & 1.19 & -0.34 & 0.83 & \\
\hline \multirow{2}{*}{$\begin{array}{l}\text { Sprovođenje istraživanja i } \\
\text { prikupljane podataka značajnih za } \\
\text { školsku praksu predstavlja veliki } \\
\text { izazov za mene. }\end{array}$} & osnovna škola & 3.45 & 1.05 & \multirow[t]{2}{*}{-0.70} & \multirow[t]{2}{*}{0.48} & \multirow[t]{2}{*}{98} \\
\hline & srednja škola & 3.60 & 1.01 & & & \\
\hline \multirow{2}{*}{$\begin{array}{l}\text { Pristalica sam uvođenja inovacija } \\
\text { u obrazovni proces. }\end{array}$} & osnovna škola & 4.31 & 0.84 & \multirow[t]{2}{*}{0.49} & \multirow[t]{2}{*}{0.66} & \multirow[t]{2}{*}{98} \\
\hline & srednja škola & 4.22 & 0.95 & & & \\
\hline
\end{tabular}




\begin{tabular}{|c|c|c|c|c|c|c|}
\hline \multirow{2}{*}{$\begin{array}{l}\text { Korišćenje računara i audio- } \\
\text { vizuelnih sredstava u nastavnom } \\
\text { procesu mi pričinjava zadovoljstvo } \\
\text { i uspešno se koristim njima. }\end{array}$} & osnovna škola & 3.96 & 1.12 & \multirow[t]{2}{*}{0.04} & \multirow[t]{2}{*}{0.40} & \multirow[t]{2}{*}{98} \\
\hline & srednja škola & 3.96 & 1.02 & & & \\
\hline \multirow{2}{*}{$\begin{array}{l}\text { Korišćenje interneta u nastavi ne } \\
\text { umanjuje moju ulogu i značaj kao } \\
\text { nastavnika. }\end{array}$} & osnovna škola & 4.24 & 0.92 & \multirow[t]{2}{*}{1.00} & \multirow[t]{2}{*}{0.91} & \multirow[t]{2}{*}{98} \\
\hline & srednja škola & 4.04 & 1.00 & & & \\
\hline \multirow{2}{*}{$\begin{array}{l}\text { Biti učesnik u projektima koje } \\
\text { organizuje Ministarstvo prosvete je } \\
\text { veliki izazov za mene. }\end{array}$} & osnovna škola & 3.44 & 1.21 & \multirow[t]{2}{*}{-0.33} & \multirow[t]{2}{*}{0.17} & \multirow[t]{2}{*}{98} \\
\hline & srednja škola & 3.51 & 1.04 & & & \\
\hline \multirow{2}{*}{$\begin{array}{l}\text { Ostvarivanje saradnje i } \\
\text { komunikacije sa roditeljima } \\
\text { učenika koji pružaju otpor } \\
\text { predstavlja veliki izazov za mene. }\end{array}$} & osnovna škola & 3.67 & 1.09 & \multirow{2}{*}{-0.18} & \multirow{2}{*}{0.82} & \multirow{2}{*}{98} \\
\hline & srednja škola & 3.71 & 1.04 & & & \\
\hline \multirow{2}{*}{$\begin{array}{l}\text { Sve veća tehnologizacija } \\
\text { obrazovnog procesa me čini } \\
\text { nekompetentnim za rad u } \\
\text { savremenoj školi. }\end{array}$} & osnovna škola & 2.04 & 1.10 & \multirow{2}{*}{-0.25} & \multirow{2}{*}{0.83} & \multirow{2}{*}{98} \\
\hline & srednja škola & 2.09 & 1.00 & & & \\
\hline
\end{tabular}

Na osnovu prikazane Tabele 2 vidimo da ne postoji statistički značajna razlika između tipa obrazovne ustanove u kojoj su ispitanici zaposleni i stavova o promenama i novim oblicima rada kao vidovima inovacija. Ispitanici su, nezavisno od toga u kojoj su obrazovnoj ustanovi zaposleni, pokazali generalno pozitivan stav prema promenama i novim oblicima rada, tako da su njihovi odgovori prilično ujednačeni, na šta nam ukazuju i vrednosti dobijenih parametara. Istovremeno, možemo zaključiti da je prisutnija veća tendencija ispitanika ka uvođenju inovacija u obrazovni proces, što bi značilo da same promene u obrazovanju i novi oblici rada predstavljaju izazov za njih, $\mathrm{p}>0,05$

Inkluzivna nastava je u poslednje vreme tema o kojoj se najviše polemiše i na čijoj se realizaciji intenzivno radi. Međutim, veliki broj škola se suočava sa nedovoljno obučenim nastavnim kadrom za realizaciju inkluzivne nastave što stvara dodatne probleme kako školi kao obrazovnoj instituciji, tako i samim nastavnicima i učenicima.

Inkluzivna nastava u velikoj meri nailazi na otpor nastavnika iz razloga što nastavnici jednostavno ne znaju na koji bi se način ophodili prema deci koja imaju bilo koji vid poremećaja. Kod njih je istovremeno prisutan strah od inkluzije, ali i nedostatak aspiracija za usavršavanjem i bavljenjem nečim novim što bi olakšalo rad deci sa smetnjama u razvoju i podiglo obrazovni proces na jedan viši nivo. Rezultati koji slede pokazuju otpor ispitanika prema ovom obliku nastave i jedan od velikih izazova sa kojima se suočavaju nastavnici refleksivni prakričari. 
Tabela 3. Stavovi ispitanika o realizaciji inkluzivne nastave s obzirom na dužinu radnog staža

\begin{tabular}{|c|c|c|c|c|c|c|}
\hline Tvrdnje & $\begin{array}{l}\text { Dužina radnog } \\
\text { staža nastavnika }\end{array}$ & M & SD & F-test & $\mathbf{p}$ & df \\
\hline \multirow{3}{*}{$\begin{array}{l}\text { Deca sa izvesnim teškoćama } \\
\text { mogu dostići svoj maksimum } \\
\text { u učenju i razvoju u okviru } \\
\text { redovne nastave. }\end{array}$} & do 10 godina & 2.65 & 1.36 & \multirow{3}{*}{0.81} & \multirow{3}{*}{0.45} & \multirow{3}{*}{99} \\
\hline & $11-20$ godina & 2.75 & 1.10 & & & \\
\hline & preko 20 godina & 2.38 & 1.18 & & & \\
\hline \multirow{4}{*}{$\begin{array}{l}\text { Prisustvo dece sa posebnim } \\
\text { potrebama u razredu deluje } \\
\text { stimulativno na nastavnika i } \\
\text { njegov rad. }\end{array}$} & do 10 godina & 2.55 & 1.36 & \multirow{3}{*}{1.05} & \multirow{3}{*}{0.36} & \multirow{3}{*}{99} \\
\hline & 11-20 godina & 2.28 & 0.99 & & & \\
\hline & preko 20 godina & 2.14 & 1.03 & & & \\
\hline & do 10 godina & 3.55 & 1.50 & \multirow{3}{*}{1.57} & \multirow{3}{*}{0.21} & \multirow{3}{*}{99} \\
\hline \multirow{2}{*}{$\begin{array}{l}\text { Zainteresovan sam za } \\
\text { proučavanje literature o } \\
\text { inkluzivnom obrazovanju. }\end{array}$} & 11-20 godina & 3.13 & 1.09 & & & \\
\hline & preko 20 godina & 3.00 & 1.25 & & & \\
\hline \multirow{3}{*}{$\begin{array}{l}\text { Nedovoljno raspolažem } \\
\text { znanjima o inkluzivnom } \\
\text { obrazovanju. }\end{array}$} & do 10 godina & 3.10 & 1.22 & \multirow{3}{*}{1.37} & \multirow{3}{*}{0.26} & \multirow{3}{*}{99} \\
\hline & 11-20 godina & 3.50 & 1.04 & & & \\
\hline & preko 20 godina & 3.52 & 1.21 & & & \\
\hline \multirow{3}{*}{$\begin{array}{l}\text { Ne znam na koji bih način } \\
\text { uspostavio odnos sa decom } \\
\text { koja imaju bilo koji oblik } \\
\text { poremećaja. }\end{array}$} & do 10 godina & 2.48 & 1.26 & \multirow{3}{*}{8.88} & \multirow{3}{*}{0.00} & \multirow{3}{*}{99} \\
\hline & 11-20 godina & 3.18 & 0.96 & & & \\
\hline & preko 20 godina & 3.62 & 0.94 & & & \\
\hline \multirow{3}{*}{$\begin{array}{l}\text { Uključivanje dece sa posebnim } \\
\text { potrebama u redovne škole ima } \\
\text { pozitivan uticaj na ostalu decu } \\
\text { u razredu. }\end{array}$} & do 10 godina & 2.13 & 1.23 & \multirow{3}{*}{0.07} & \multirow{3}{*}{0.93} & \multirow{3}{*}{99} \\
\hline & 11-20 godina & 2.23 & 0.97 & & & \\
\hline & preko 20 godina & 2.17 & 1.00 & & & \\
\hline \multirow{3}{*}{$\begin{array}{l}\text { Prisustvo dece sa posebnim } \\
\text { potrebama ometa moj rad sa } \\
\text { ostalom decom u razredu. }\end{array}$} & do 10 godina & 3.06 & 1.31 & \multirow{3}{*}{0.87} & \multirow{3}{*}{0.42} & \multirow{3}{*}{99} \\
\hline & 11-20 godina & 3.40 & 1.13 & & & \\
\hline & preko 20 godina & 3.41 & 1.15 & & & \\
\hline \multirow{3}{*}{$\begin{array}{l}\text { Inkluzivno obrazovanje } \\
\text { predstavlja korak ka } \\
\text { humanizaciji odnosa u školi } \\
\text { i jedan od profesionalnih } \\
\text { izazova. }\end{array}$} & do 10 godina & 3.06 & 1.36 & \multirow{3}{*}{1.95} & \multirow{3}{*}{0.15} & \multirow{3}{*}{99} \\
\hline & $11-20$ godina & 3.55 & 1.11 & & & \\
\hline & preko 20 godina & 3.14 & 0.83 & & & \\
\hline
\end{tabular}

$\mathrm{Na}$ osnovu prikazane tabele, možemo videti da postoji statistički značajna razlika između stavova ispitanika s obzirom na dužinu radnog staža po pitanju tvrdnje Ne znam na koji bih način uspostavio odnos sa decom koja imaju bilo koji oblik poremećaja, u okviru koje imamo nešto veće slaganje nastavnika koji imaju radni staž preko 20 godina, nego ostalih nastavnika, na šta nam ukazuju dobijene aritmetičke sredine i standardne devijacije, kao i t-test, p i stepen slobode. Dobijene vrednosti su značajne na nivou značajnosti od 0,05 , jer p iznosi 0,00 .

Kod ostalih tvrdnji nemamo dobijenu statistički značajnu razliku u odgovorima ispitanika u odnosu na dužinu radnog staža nastavnika, $p>0,05$. 


\section{Zaljučna razmatranja}

Novi zahtevi modernog obrazovnog sistema nametnuli su potrebu za osavremenjivanjem sistema i sadržaja obrazovanja nastavnika. Opštom strukturom studijskih programa potrebno je težiti podsticanju profesionalne autonomije i refleksivne prakse nastavnika. Potrebno je da oni steknu znanja, izgrade stavove i praktične sposobnosti koje će im pomoći da se stalno stručno usavršavaju. Usavršavanje je pretpostavka unapređivanja i osavremenjivanja vaspitno-obrazovnog procesa, pa usavršavanje mora dobiti obeležje permanentne, planske, organizovane i kontinuirane delatnosti. Vaspitno-obrazovni sistem, kao deo ukupnog sistema društva, mora se stalno reformisati i usavršavati kako bi odgovorio svim zahtevima koji su mu postavljeni. Sa kojim izazovima sa danas nastavnici susreću je ključno pitanje na koje smo pokušali da damo odgovore.

Sa razvojem nauke i sa uvođenjem brojnih promena u obrazovno-vaspitni sistem, nastavnici su se našli pred brojnim izazovima od koji ne smeju bežati, već sa kojima se moraju suočiti i uskladiti ih sa svojim sistemom vrednosti, stilom rada $i$ ličnošću, ukoliko žele biti uspešni u svom poslu.

Ovo istraživanje bi trebalo da pokrene pitanje usavršavanja nastavnika za inkluzivno obrazovanje, kako bi i rezultati u sprovođenju tog obrazovanja bili uspešniji. Instrument istraživanja je pokazao dobru unutrašnju konzistentnost, stoga bi bilo dobro ponoviti istraživanje posle izvesnog vremena na istu temu. Njihove pozitivne stavove prema promenama bi trebalo iskoristiti upravo u pravcu daljeg unapređivanja inkluzivnog obrazovanja.

\section{Literatura}

Bjekić, D. (1999). Profesionalni razvoj nastavnika. Užice: Učiteljski fakultet.

Dedaj, M. (2011). Inkluzivni razvoj škole. Pedagoška stvarnost, 57(5-6), 558-565.

Dimitrijević, Ž. (2010). Posebne potrebe i inkluzivno obrazovanje - Zakonodavni okvir Srbije. Socijalna misao, 17(2), 175-184.

Džinović, V. (2010). Principi podsticanja individualne promene u profesionalnom razvoju nastavnika. U: N. Polovina, N. i J. Pavlović (ur.) Teorija i praksa profesionalnog razvoja (147-171).

Golubović, Š. i Maksimović, J. (2008). Uloge i zadaci učitelja u procesu inkluzivnog obrazovanja. Pedagoška stvarnost, (1-2), 49-56, Novi Sad.

Grandić, R. i Stipić, M. (2011). Profesionalni razvoj nastavnika- put do kvalitetnog obrazovanja. Pedagoška stvarnost, 57(3-4) 198-209.

Grujić, Lj. (2011). Profesionalno sagorevanje nastavnika. Pedagogija, 66(2), 215-223.

Hozić, I. (2009). Inkluzija za sve. Pedagoška stvarnost, 54(3-4), 440-445

Huberman, M. (1995). Professional careers and professional development: Some intersections. In T.R. 
Maksimović, J. i Banđur, V. (2013). Obrazovanje nastavnika refleksivnog praktičara. Teme, 37(2), 595-610.

Petković, V. (2009). Škola u inkluzivnom kontekstu. Norma, 14(1), 69-75, Novi Sad.

Stanković D. i Pavlović, J. (2010). Modeli profesionalnog razvoja nastavnika. U: N. Polovina i J. Pavlović (ur.) Teorija i praksa profesionalnog razvoja (17-41). Beograd: Institut za pedagoška istraživanja.

Vlahović B. i Vujisić-Živković, N. (2005). Nastavnik - izazovi profesionalizacije. Beograd: Forum pedagoga Srbije i Crne Gore, Eduka.

\title{
REFLECTIVE EDUCATION FOR INCLUSIVE TE- ACHING - STATE AND PERSPECTIVE
}

\author{
Jelena Maksimović, Jelena Osmanović \\ University of Niš, Faculty of Philosophy, Niš, Department of Pedagogy
}

\begin{abstract}
The challenges faced by teachers vary in relation to whether a teacher works with elementary or high school students. Considering that with this research we want to discover and point out the most important challenges teachers face, we will devote special attention to analyzing the role of teachers of reflexive practitioners in the inclusive teaching process as one of the potential challenges that it faces on the path of professional development, at least partly contribute to ease their further work and make it more efficient. The results of the research shows that teachers, regardless of whether they work in elementary or secondary schools, are susceptible to changes that occur. If they are open, the question arises why they showed disapproval and reservations about the implementation of inclusive teaching? The research involved 209 teachers in the territory of the city of Niš. The data are presented by descriptive analysis and tabular.
\end{abstract}

Key Words: reflexive education, reflexive practice, reflexive practitioner, innovation in education, inclusive education.

\section{Citiranje članka:}

Maksimović, J. i Osmanović, J. (2017). Refleksivno obrazovanje za inkluzivnu nastavu stanje i perspektive. Godišnjak za pedagogiju, 2(1), 31-39. 
